\title{
The international regimes for the compensation of oil pollution damage: are they effective?
}

Citation for published version (APA):

Faure, M. G., \& Wang, H. (2003). The international regimes for the compensation of oil pollution damage: are they effective? Review of European Community and International Environmental Law, 12(3), $242-253$. https://doi.org/10.1111/1467-9388.00367

Document status and date:

Published: 01/01/2003

DOI:

10.1111/1467-9388.00367

Document Version:

Publisher's PDF, also known as Version of record

\section{Please check the document version of this publication:}

- A submitted manuscript is the version of the article upon submission and before peer-review. There can be important differences between the submitted version and the official published version of record.

People interested in the research are advised to contact the author for the final version of the publication, or visit the DOI to the publisher's website.

- The final author version and the galley proof are versions of the publication after peer review.

- The final published version features the final layout of the paper including the volume, issue and page numbers.

Link to publication

\footnotetext{
General rights rights.

- You may freely distribute the URL identifying the publication in the public portal. please follow below link for the End User Agreement:

www.umlib.nl/taverne-license

Take down policy

If you believe that this document breaches copyright please contact us at:

repository@maastrichtuniversity.nl

providing details and we will investigate your claim.
}

Copyright and moral rights for the publications made accessible in the public portal are retained by the authors and/or other copyright owners and it is a condition of accessing publications that users recognise and abide by the legal requirements associated with these

- Users may download and print one copy of any publication from the public portal for the purpose of private study or research.

- You may not further distribute the material or use it for any profit-making activity or commercial gain

If the publication is distributed under the terms of Article $25 \mathrm{fa}$ of the Dutch Copyright Act, indicated by the "Taverne" license above, 


\section{The International Regimes for the Compensation of Oil-Pollution Damage: Are they Effective?}

\section{Michael Faure and Wang Hui}

\section{INTRODUCTION}

The increasing sea-borne transport of oil and hazardous substances constitutes a growing pollution risk, and a threat to the seas and oceans. Among all the contaminants from ships, oil probably has the highest public profile. Since the Torrey Canyon disaster in 1967, marine oil pollution has been a source of worry worldwide. After the first serious incidents with oil tankers, international conventions came into being dealing with oil pollution at different stages. Depending upon their purpose and function, some of them can be categorized as safety regulations designed to prevent oil spills, some as contingency plans, and others as compensation schemes for the victims of marine oil pollution. It is the latter type of conventions that is discussed within the scope of this article.

Indeed, marine oil-pollution conventions have specific features that depart in important ways from traditional civil liability regimes. For instance, they provide for mandatory provision of financial coverage of the (strict) liability of the tanker owner, but their liability is limited to a specific amount. These financial limits (also referred to as caps) originated from maritime law, where there has been a long tradition of the limitation of liability of the carrier. The conventions only apply the liability to the tanker owner, excluding liability of others who may have contributed to the risk. This is referred to as the so-called 'channelling' of liability.

The Civil Liability Convention (the CLC 1969) was adopted in 1969. ${ }^{1}$ The liability regime of the convention was supplemented by a convention establishing an international fund for compensation for oil-pollution damage (the Fund Convention) in $1971,{ }^{2}$ with the goal of providing additional compensation to victims. Many serious subsequent oil-pollution incidents led

\footnotetext{
'International Convention on Civil Liability for Oil Pollution Damage (Brussels, 29 November 1969) (hereinafter CLC 1969).

${ }^{2}$ International Convention on the Establishment of an International Fund for Compensation for Oil Pollution Damage (Brussels, 18 December 1971) (hereinafter the Fund Convention).
}

to various protocols and amendments as it became ever more clear that the original caps were largely insufficient. Today, the question arises whether the international regimes for the compensation of pollution damage are indeed still effective. This question is increasingly posed after major incidents, such as the losses of the Erika and the Prestige, which showed the inadequacy. This led, among others, to regional organizations such as the European Union taking their own initiatives for supplementary European funds.

These and other developments raise the question whether the current international regimes are adequate for the compensation of oil-pollution damage. This article sketches the regime of the CLC 1969 and the Fund Convention. It will show that following the Amoco Cadiz in 1978, and other catastrophes, new initiatives were taken with the goal of providing more compensation. In 2000, following the Erika incident, the International Maritime Organization (IMO) Legal Committee proposed new amendments, which are to take effect in November 2003. However, even before this new regime has entered into force, the sinking of the Prestige in November 2002 has cast doubt on whether this new regime is indeed sufficient to deal with major oil spills. Hence, this article will address some of the critical issues underlying the current structure of the regime and discuss possible future developments, as indicated in doctrine and at the policy level. Finally, the article formulates concluding remarks.

\section{CLC 1969 AND THE FUND CONVENTION}

\section{PRE-1969 REGME}

Until 1969, there were no international conventions that specifically addressed the liability for ships that caused marine pollution. Liability for oil-pollution damage was generally limited to the vessel's liability tonnage with amounts limited under the 1957 International Convention Relating to the Limitation of 
Liability of Owners of Sea-Going Ships. ${ }^{3}$ In countries that were not a party to the convention, liability was limited to the total value of ship and cargo.

The Torrey Canyon disaster in 1967 constituted a turning point. The maritime world realized that it was not prepared for such major pollution incidents. This resulted in intense activities at national and international levels. ${ }^{4}$ The International Maritime Consultative Organization (IMCO, now IMO) produced two international conventions - the CLC 1969 and the Fund Convention in 1971, which turned out to be the basis of the oil-pollution liability system, which emerged in the following years. In addition, the shipping industry and the oil industry produced two private schemes: TOVALOP in 1969 and CRISTAL in 1971.

\section{THE 1969/1971 REGIME}

CLC 1969 Although it is now in the process of being superseded by the CLC Protocol 1992, ${ }^{5}$ the CLC 1969 still remains the essence of oil-pollution liability laws in many parts of the world. ${ }^{6}$ The convention has set up strict liability for the owner of a tanker that causes the pollution, although, under certain circumstances, the owner enjoys limitation of liability. It also requires compulsory insurance for the tanker owner as a basic principle.

Strict Liability Under the CLC 1969, ship owners are held strictly liable whenever an oil spill occurs. Apparently, the introduction of strict liability for oilpollution damage was not accepted easily at the negotiations preceding the convention. Many countries with large tanker fleets initially opposed the strict liability requirement, but finally the delegates accepted the description proposed by IMO, which weakened the limitation of liability. Moreover, in some specific cases, the tanker owner is not strictly liable under

\footnotetext{
${ }^{3}$ International Convention Relating to the Limitation of Liability of Owners of Sea-Going Ships (Brussels, 10 October 1957).

${ }^{4} \mathrm{~A}$. Blanco-Bazan, The Erika Casualty, Legal Issues from the IMO View (International Union of Marine Insurance 2000 Conference, London, 10-13 September 2000). There were discussions on proper implementation of existing rules versus the effectiveness of the current rules.

${ }^{5}$ Protocol to the CLC 1969 (London, 27 November 1992)

${ }^{6}$ The CLC 1969's formal goal was to ensure that adequate compensation is available to persons who suffer oil-pollution damage resulting from maritime casualties involving oil-carrying ships. See CLC 1969. Preamble; D. Abecassis, 'IMO and Liability for Oil Pollution from Ships: A Retrospective', Lloyds Maritime and Commercial Law Quarterly (1983), at 45-46; E.H.P. Brans, Liability for Damage to Public Natural Resources: Standing, Damage and Damage Assessments (Kluwer Law International, 2001), at 315-316; E. Gold, Handbook on Marine Pollution (Gard, 1985), at 44-47; Z. Oya Özçayir, Liability for Oil Pollution and Collisions (Lloyds of London Press, 1998), at 211-218

certain conditions; for instance, if the damage is the consequence of an act of war or if the damage is exclusively caused by the intentional act or negligence of a third party.?

As Chen rightly points out, the replacement of traditional fault-based liability by strict liability may now sound common-place in the context of current international environmental law, but it was certainly considered as extraordinary and innovative when the CLC 1969 came into being. ${ }^{8}$

Compulsory Insurance The CLC 1969 states that an owner of a tanker carrying more than 2000 tons of persistent oil as cargo is obliged to maintain insurance or other financial security to cover his liability. ${ }^{9}$ The victims may, in addition, bring legal action directly against the tanker's insurer. The CLC 1969 stipulates that the vessel should prove the availability of insurance or another form of financial security to cover its liability. As proof of the availability of financial security, the vessel must carry a certificate. ${ }^{10}$ Article VII(8) of the convention holds that claims for compensation can be directed against the insurer. The insurer can call on the limitation of liability insofar as the insured tanker owners were able to call on this limitation themselves.

The goal of the CLC 1969 is to ensure that tanker owners have appropriate levels of insurance to cover their potential liabilities for pollution damage. ${ }^{11}$ However, how to set the optimal level of insurance remains a critical issue.

Limitation of Liability The CLC 1969 does not require an owner to be insured beyond the amount to which he could limit his liability under Article V(1). Under the CLC 1969, the amount of compensation available from ship owners caused great concern for the insurance industry. At that time, it was considered that if more compensation was required from ship owners, this might lead to an uninsurable increase in

\footnotetext{
${ }^{7}$ See CLC 1969, Article III(2).

${ }^{8}$ See X. Chen, Limitation of Liability for Maritime Claims: A study of US Law, Chinese Law and International Conventions (Kluwer Law International, 2001), at 140; and see M. Jacobsson, 'The International Conventions on Liability and Compensation for Oil Pollution Damage and the Activities of the International Oil Pollution Compensation Fund', in C. De La Rue (ed.), Liability for Damage to the Marine Environment (Lloyds of London Press, 1993), at 41.

${ }^{9}$ CLC 1969, Article VII(1)

${ }^{10}$ The contents of this certificate are fixed in Article VII(2) of the convention. For further details see E. Gold, n. 6 above, at 45. See also Z. Oya Özçayir, n. 6 above, at 215-217.

${ }^{11}$ See K. Le Couviour, "Responsabilité pour pollutions majeures résultant du transport maritime d'hydrocarbures: Après l'Erika, le Prestige... L'impératif de responsabilisation', 51-52 La Semaine Juridique (JCP) (18 December 2002), at 2271.
} 
claims. The UK, having a large protection and indemnity (P\&I) club industry, was opposed to high limits of liability, as it believed that high limits would dry up the funds that were available in the global insurance market. ${ }^{12}$

The liability was limited in respect of any one incident to 133 special drawing rights (SDR) ${ }^{13}$ for each tonne of the ship's gross tonnage with a maximum liability of 14 million SDR (around US $\$ 18$ million for each incident). The argument goes that the limitation provided makes this insurance coverage possible. ${ }^{14}$ If the limitation were not predictable or even unlimited, the insurers would not be able to assess the magnitude of the risks and set an appropriate premium, and it would also be difficult for ship owners to shift the risks to their liability insurance. If the ship owner was to take unlimited responsibility, the insurers would set the premium accordingly at an extremely high level, which might then be unaffordable for the ship owners. ${ }^{15}$

These financial caps are, at least towards third parties, often considered inefficient since they lower the incentives to take care and may thus confront the insurer with a moral hazard problem. ${ }^{16}$ Therefore, financial limits are paradoxical, since they, on the one hand, are introduced to make the risks insurable, but also could lead to moral hazard. ${ }^{17}$

\section{Fund Convention of 1971}

Although the CLC 1969 provided a useful mechanism for ensuring the payment of compensation for oilpollution damage, it did not deal satisfactorily with all the legal, financial and other questions raised during the IMO conference in 1969 when the CLC 1969 was created. Some States objected to the establishment of the regime, since it was based on the strict liability of the ship owner for damage, which he could not foresee, and, therefore, represented a dramatic departure from traditional maritime law, which based liability on

\footnotetext{
${ }^{12}$ B. Browne, Port Authorities and Marine Oil Pollution Compensation (Clyde and Co., 1998).

${ }^{13}$ The way the limits were calculated has changed over time. The first reference was made to gold francs, to be converted into national currency; later the limits were calculated in drawing rights on the International Monetary Fund (IMF). Today, CLC 1969, Article $V$ refers to 'Units of Account'. According to Article $V(9)$ this still is the special drawing right as defined by the IMF.

${ }^{14}$ See K. Le Couviour, n. 11 above, at 2271.

${ }^{15} \mathrm{E}$. Rosoeg. The Impact of Insurance Practices on Liability Conventions (Scandinavian Institute of Maritime Law, 2000).

${ }^{16}$ Moral hazard is the well-known phenomenon in insurance that an insured may, as a result of being fully covered by insurance and no longer exposed to risk, change his conduct towards less carefut, more risky behaviour. See generally $S$. Shavell, 'On Moral Hazard and Insurance', 93:4 Quarterly Journal of Economics (1979), at $541-562$.

${ }^{17} \mathrm{~K}$. Bolin. The Ownership of Funds and Systems for Reparation of Very Large Accidents (European Science Foundation's Conference on Risks and Insurance, 1998)
}

fault. On the other hand, some States felt that the limitation figures adopted were likely to be inadequate in cases of oil-pollution damage involving large tankers. They therefore pleaded in favour of an unlimited level of compensation or a very high limitation figure. $^{18}$

Following the mandate conferred by the 1969 conference, the Legal Committee of the IMO prepared a draft treaty, which was submitted to a diplomatic conference convened in Brussels in December 1971. The conference adopted the Fund Convention. Since the ceiling level of compensation under the CLC 1969 was considered not high enough to compensate the victims in cases of serious oil spills, the Fund Convention addressed the question of compensation by vesting obligations on oil cargo owners. It does not impose liability on individual cargo owners, but provides that compensation is to be paid by an intergovernmental body known as the International Oil Pollution Compensation (IOPC) Fund (hereinafter the IOPC Fund or the Fund), to which the contributors are the oil receivers. This Fund was meant to cover the damage not covered by CLC 1969, and thus to relieve ship owners from the additional financial burden imposed by the convention. ${ }^{19}$

From the perspective of national interests, the Contracting States to the Fund Convention were to inform the IOPC Fund of the persons liable to contribute, but no extra costs were imposed on the State government. Hence, within this system, it is the oil-receiving companies, not the Contracting States, who must contribute. Therefore, this system may give incentives to States to join the Fund Convention. Many scholars hold that the combination of the CLC 1969 and the IOPC Fund leads to a sharing of the costs of oil-pollution damage between vessel owners and the oil industry. ${ }^{20}$

Voluntary Schemes In the wake of intense discussions after the Torrey Canyon disaster, some voluntary schemes were set up by the tanker and oil industries to encourage prompt and effective clean-up and to assure adequate and timely compensation. This system of compensation consists of two steps. In the first step, the individual tanker owner whose vessel causes a spill is responsible. In the second step, the responsibility of the cargo owner starts where the

\footnotetext{
${ }^{18} \mathrm{P}$. Bennett, Mutual Risk: P\&I Insurance Clubs and Maritime Safety and Environmental Performance', 25:1 Marine Policy (2001) at $13-21$.

${ }^{13}$ See X. Chen, n. 8 above, at 142-143; and see also M. Jacobsson, n. 8 above, at $39-56$; E.H.P. Brans, n. 6 above, at $317-318$.

${ }^{20}$ See D. Abecassis, n. 6 above, at 47 ; J. Bongaerts and A. De Bièvre, 'Insurance for Civil Liability for Marine Oil Pollution Damages', The Geneva Papers on Risk and Insurance (1987), at 148; see also E. Gold. n. 6 above, at 115 .
} 
tanker owner's applicable limit of liability is exceeded. This division was worked out in two separate schemes: Tanker Owners Voluntary Agreement concerning Liability for Oil Pollution (TOVLAP) and Contract Regarding an Interim Supplement to Tanker Liability for Oil Pollution (CRISTAL). ${ }^{21}$

\section{TOVALOP}

Seven ship owners, including the oil companies British Petroleum, Mobil Oil, Shell and Texaco, signed the TOVALOP in 1969. Originally, TOVALOP was created as a stop-gap measure while the CLC 1969 was being implemented. ${ }^{22}$ When the CLC 1969 came into force in 1975, the question arose whether TOVALOP was still necessary. The TOVALOP Standing Agreement (TSA) was established in 1978, the year in which the entire international regime of the CLC 1969 and the Fund Convention became effective. TSA applied only when the CLC 1969 did not apply. ${ }^{23}$ It can hence be seen as a residual scheme. One of its main advantages is that it allows for reimbursement of the costs of preventive measures taken in case of a threat of pollution. It also includes tankers in ballast, which are excluded from the CLC 1969. Moreover, the procedure of settlement of claims is quick and inexpensive.

\section{CRISTAL}

As a reaction to the Fund Convention, another voluntary agreement came into being, the so-called CRISTAL. CRISTAL was also a voluntary industry agreement designed to address oil pollution by supplementing TOVALOP, but unlike TOVALOP, the parties to CRISTAL were not tanker owners, but oil companies. CRISTAL was conceived as an interim arrangement pending the entry into force of the Fund Convention and was supposed to offer compensation to supplement the financial obligations laid down in TOVALOP if this compensation proved to be insufficient.

The industry scheme, whereby tanker owners and oil importers undertook voluntary liability to pay compensation for oil-pollution damage, not only had an impact on world opinion, but also relieved pressure on national governments to introduce their own unilateral solutions. ${ }^{24}$ The CRISTAL Fund had amounts

\footnotetext{
${ }^{21}$ See C. White, 'The Voluntary Oil Spill Compensation Agreements - TOVALOP and CRISTAL', in C. De La Rue, n. 8 above, at 57-70.

${ }^{22}$ As of 1987 , over $98 \%$ of the world's tanker owners, including many government-owned fleets, had become signatories to TOVALOP. See S. Bloodworth, 'Death on the High Seas: The Demise of TOVALOP and CRISTAL', 13:2 Florida State University Journal of Land Use \& Environmental Law (1998), 443; also see L.G. Cohen, 'Revisions of TOVALOP and CRISTAL: Strong Ships for Stormy Seas', 18 J. Mar. L. \& Com. (1987), 525, at 526.

${ }^{23}$ See J. Bongaerts and A. De Bièvre, n. 20 above, at 147-148; and E. Gold, n. 6 above, at $25-26$.

${ }^{24}$ CRISTAL was considered an important precedent as it showed that the oil industry could, under pressure of public opinion, take responsibility for oil-pollution damage. See E. Gold, ibid., at 26.
}

from between US\$3 million and US $\$ 5$ million at its disposition. ${ }^{25}$ Hence, industry had a clear interest in the introduction of these voluntary solutions.

\section{THE PROTOCOLS}

\section{THE 1984 PROTOCOLS}

After the adoption of the CLC 1969 and the Fund Convention, the gross volume of spilled oil declined in the 1970 s. $^{26}$ However, the serious damage caused by Amoco Cadiz $^{27}$ in 1978 showed that the old regimes were ineffective and inadequate in cases of a major oil spill. Hence, the financial limits under the old regimes were faced with an urgent need for reform.

Consequently, soon after entry into force in 1975 of the CLC 1969, informal consultations commenced aimed at increasing the amount of compensation under the two conventions. In 1984, two protocols were adopted to achieve this objective: the Protocol of 1984 to amend the International Convention on Civil Liability for Pollution Damage 1969; and the Protocol of 1984 to amend the International Convention on the Establishment of an International Fund for Compensation of Oil Pollution Damage $1971 .^{28}$

The protocols indeed increased the financial limits. However, they were designed to fail, since the conditions for their entry into force could not be met without American participation. ${ }^{29}$ The Americans strongly rejected the idea of limited liability and believed polluters should suffer unlimited liability for the damage caused. ${ }^{30}$ As a consequence, these protocols have never entered into force.

The USA is one of the largest consumers of oil in the world and one of the largest shipping nations. Therefore, its participation in the old regime would have

\footnotetext{
25 lbid., at 117.

${ }^{26}$ See M. Jöransson, 'The 1984 and 1992 Protocols to the Civil Liability Convention 1969 and the Fund Convention 1971', in C. De La Rue, n. 8 above, at $71-82$.

${ }^{27}$ Claims arising out of the incident were litigated in the USA against Standard Oil of Indiana, which actually controlled the operations of the tanker, but which was not the registered owner. In this way the restraints of the CLC 1969 , including its inadequate limits, were avoided. For an instructive account, see E. Fontaine, The French Experience of Tanio and Amoco Cadiz: Incidents Compared (Committee Maritime International - Genoa Seminar, 21-23 September 1992).

${ }^{28}$ See Z. Oya Özçayir, n. 6 above, at 223-225. See Protocol to Amend the International Convention on Civil Liability for Oil Pollution Damage (London, 25 May 1984); and Protocol to Amend the International Convention on the Establishment of an International Fund for Compensation for Oil Pollution Damage (London, 25 May 1984). It would enter into force 12 months after being accepted by 10 States, including six with tanker fleets of at least 1 million gross tons.

${ }^{29}$ See X. Chen, n. 8 above, at 141.

${ }^{30}$ See Z. Oya Özçayir, n. 6 above, at 234
} 
greatly changed the situation of the international system, especially from a financial point of view - the USA would have been the most important contributor to the IOPC Fund. Approval of the USA would have helped establish a uniform international oil-pollution liability regime. However, the USA did not join the international conventions, but enacted its own regime instead: the Oil Pollution Act was adopted in 1990, which contains several features incompatible with the international regime and thus effectively closes the door to US participation in the international scheme. ${ }^{31}$

The changes, particularly the increase in compensation amounts agreed in the 1984 protocols, were urgently needed, as demonstrated by a series of further incidents, notably the accident with the Haven in April 1991 off the coast of northern Italy. Accordingly, there was growing sentiment, especially among the European members of the IOPC Fund, that something had to be done to bring the substance of those instruments into force in order to keep the international system up to date and avoid the threat of further regional schemes.

\section{THE 1992 PROTOCOLS}

The 1992 protocols are almost identical in substance to the 1984 protocols ${ }^{32}$ but there was a change to the entry into force provision, which eliminated the need for US participation. The new protocols also provided for an increase in the financial limits. The compensation limits in the 1992 protocols are those originally agreed in 1984:

- for a ship not exceeding 5000 gross tonnage, liability is limited to 3 million SDR (about US $\$ 3.8$ million);

- for a ship of 5,000-140,000 gross tonnage, liability is limited to 3 million SDR +420 SDR (about US $\$ 538$ ) for each additional unit of tonnage;

- for a ship over 140,000 gross tonnage, liability is limited to 59.7 million SDR (about US $\$ 76.5$ million).

The new protocols entered into force on 30 May 1996.33

\footnotetext{
${ }^{31}$ See Oil Pollution Act of 1990, 33 U.S. Code 2701-2761. See also A.H.E. Popp, Oil Spills - Who Pays for Them and How Much? An overview of the International Compensation System (Ninth International Oil Spill Conference, Sydney, Australia, 16-20 September 2002), at 5 .

${ }^{32}$ See Protocol to the CLC 1969, n. 5 above, and Protocol to the 1971 Oil Pollution Fund Convention (London, 27 November 1992).

${ }^{33}$ For an excellent overview of the contents and importance of the 1992 Protocols see E.H.P. Brans, 'Liability for Ecological Damage under the 1992 Protocols to the Civil Liability Convention and the Fund Convention, and the Oil Pollution Act of 1990', Tijdschrift voor Milieuaansprakelijkheid (Environmental Liability Law Review) (1994), at 61-67 and 85-91; and see E.H.P. Brans, n. 6 above, at 344-360.

(1) Blackwell Publishing Ltd. 2003
}

The international system had encountered many problems during its 20 years of application. In addition to the problem of insufficient compensation, two other problems have been intrinsic to the international system: first, the refusal by the IOPC Fund to cover environmental damages; second, the lack of effective sanctions to the pollution-prevention system. ${ }^{34}$ The refusal of the USA to take part in the international regime has also posed an obstacle to the highlighted concerted international efforts at controlling oil pollution by ship. ${ }^{35}$

France played an important role in the revision process because it had suffered the greatest exposure to the risks of oil spills. During the negotiations of the protocols, the French delegation proposed an increase of the amount of compensation available from the IOPC Fund. ${ }^{36}$ Another problem raised was the need to extend the field of application of the conventions: some of the terms of the CLC 1969 and the Fund Convention needed to be redefined to give a broader scope to the conventions.

The 1992 protocols thus came into force with a substantial increase of limitation of liability in comparison with the old regime of the CLC 1969 and Fund Convention. The amounts available after the entry into force of the 1992 protocols were, thus, substantially increased, as indicated above. However, the basic principle of a joint contribution by the oil industry and the shipping industry, as well as strict liability of the tanker owner with financial caps on liability, remained in existence.

\section{DISAPPEARANCE OF TOVALOP AND CRISTAL}

For many years, the industry schemes TOVALOP and CRISTAL provided a worldwide voluntary scheme of compensation for pollution from tankers. However, these voluntary schemes were considered to have fulfilled their intended purposes with the entry into force of the 1992 protocols and were thus abrogated on 20 February 1997.

\footnotetext{
${ }^{34}$ See A. Blanco-Bazan, n. 4 above, at $6-8$.

${ }^{35}$ Committee Maritime International (CMI), Guidelines on Oil Pollution Damage, adopted at the Thirty-Fifth International Conference of CMI (Sydney, 2-8 October 1994). CMI has as its objective the unification of maritime law. There were concerns that increasing public interest in environmental issues would lead to growing problems due to legal uncertainty in this field. The problem was highlighted in 1990 when the USA decided to adopt its own system (the Oil Pollution Act of 1990), instead of joining the international scheme. The US Oil Pollution Act has adopted some principles which are incompatible with the international regime. For instance, see Oil Pollution Act, n. 31 above, Sections 1001-1003.

${ }^{36}$ They succeeded in the sense that the limit was substantially increased in the end.
} 
In countries that have not ratified or acceded to the CLC 1969, TOVALOP was usually the principal mechanism for compensating victims of oil pollution from tankers under the applicable local law. There were even cases where TOVALOP, especially the TOVALOP Supplement, could be involved in responding to a spill in a country that was a party to the CLC 1969 .

The rapid growth in acceptance by maritime States of the CLC 1969 and Fund Convention led to the decision to end TOVALOP and CRISTAL on 20 February 1997. The International Tanker Owners Pollution Federation (ITOPF), originally established to administer the TOVALOP voluntary agreement, became a provider of specialized technical services in the field of marine oil pollution, arranged through the P\&I clubs and other oil-pollution insurers. The organization currently has some 4000 tanker-owner members, who between them own or operate some $98 \%$ of the world's tankvessel tonnage. ${ }^{37}$

The disappearance of TOVALOP and CRISTAL has had a significant effect on the handling of marinepollution compensation claims from tankers in nonconvention States. In the case of pollution in the waters of a non-convention country, and in the absence of the voluntary agreements, the claim would be brought under the domestic legislation of that State, often against a flag-of-convenience company with no assets.

\section{WINDING UP OF THE 1969/ 1971 REGIME}

As of 16 May 1998, parties to the 1992 protocols ceased to be parties to the CLC 1969 and the Fund Convention due to a mechanism of compulsory denunciation of the old regime established in the 1992 protocols. However, the two regimes continued to coexist, since there are a number of States still party to the 1969 and the 1971 conventions that have not yet ratified the 1992 protocols. ${ }^{38}$

On 24 May 2002, the Fund Convention ceased to be in force. Even if it were not abolished, the regime has lost its financial basis; hence any States that remained in the regime would be faced with serious financial disadvantages. Either the Fund would not be able to pay compensation to victims since there would be few

\footnotetext{
${ }^{37}$ See the ITOPF website available at <http://www.itopf.com>.

${ }^{38}$ As at 1 February 2003, 91 States had ratified the 1992 CLC Protocol and 84 States had ratified the 1992 Fund Protocol, while only 48 States were still party to the CLC 1969 (statistics from the website of the IOPC Fund, ibid.).
}

or no contributors in the remaining Contracting States, or the remaining contributors would be called upon to provide a much greater proportion of the compensation than before.

In order to avoid these damaging consequences, the IMO and the IOPC Fund Secretariat have been working actively to encourage the remaining governments to accede to the 1992 protocols and to denounce the 1969 and 1971 regimes. $^{39}$

\section{THE 2000 REGIME}

The legal regime concerning the damage caused by oil pollution has been rapidly evolving. This is partially due to new incidents, showing the inadequacy of the current regime. Following the Erika incident in 1999, a $50 \%$ increase in the amounts available under the 1992 protocols was agreed by the IMO Legal Committee in October 2000; this latest change will take effect from November 2003.

\section{BACKGROUND}

The adoption of the increased limits comes in the wake of two major incidents - the wreck of the Nakhodka in 1997 off Japan and the Erika disaster off the coast of France in December 1999, which are the only two relevant oil-pollution incidents that have exceeded the compensation limits provided under the CLC Protocol 1992.40

The Erika, an Italian-owned oil tanker of some 37,000 deadweight tons and registered in Malta, broke up on 12 December 1999, polluting 400 kilometres of the French coastline with its cargo of heavy fuel oil. The consequences of the accident generated countless hours of discussion, proposals and counter-proposals, which resulted in the accelerated phase-out of singlehull tankers and increased compensation for the victims of oil-pollution damage. ${ }^{41}$ However, the International Group of P\&I Clubs are of the view that the current international compensation regime has been

\footnotetext{
${ }^{39}$ Explanatory note prepared by the 1992 Fund Secretariat, The International Oil Pollution Compensation Fund 1992, available at ibid.

${ }^{40}$ Oil Pollution Liability and European Dimension (ICS, 2002); see the website of Maritime International Secretariat Services Ltd (MARISEC), available at <http://www.marisec.org>

${ }^{41}$ See on the incident with the Erika and the consequences for further (European) action towards the prevention of oil spills: C. Roche, 'Après l'Erika: la prevention de la pollution des mers par le renforcement de la sécurité maritime en Europe (Erika l)', Revue Juridique de l'Environnement (2002/3), at 373-392; and see K. Le Couviour, n. 11 above, at 2269-2272.
} 
quite successful, and they fear that to amend the convention in substance would destroy the system. ${ }^{42}$

The European Commission has played a central role in the process of updating the international regime of oil-pollution compensation; its influence in matters of maritime safety and environmental protection has unquestionably grown. ${ }^{43}$ The loss of the Erika may have been the catalyst, but several other recent highprofile incidents also involved European-owned vessels in European waters - the Ievoli Sun, the Castor, the Kristal, the Prestige and others. In the circumstances, the pace of European activity is unlikely to wane.

Concerning the inadequate limits of liability, the increases in compensation limits have been given urgency by moves within the European Commission to establish a separate European Community compensation fund, the so-called COPE (Compensation for Oil Pollution in Europe) Fund, constituting a third tier of compensation (up to one billion euros), in response to the perceived shortfall of the international oilpollution liability funds. ${ }^{44}$

Concerning the inappropriate balance between responsibilities of different players and their exposure to liability, and the ship owners' unbreakable limitation rights, the Commission has criticized the central role played by private organizations in the area of maritime safety, developing rules more directly to regulate classification societies (responsible for verifying the seaworthiness of vessels) and recommending amendments to the CLC Protocol 1992 to weaken ship-owner limitation of liability rights.

Behind the latter proposal lies the view that the tight interdependence between the P\&I clubs and the ship

\footnotetext{
${ }^{42}$ Review of the International Compensation Regime, submission of the International Group of P\&I Clubs (92FUND/WRG.3/1417, 20 January 2003). It was argued in the review that the widespread adoption of the conventions is not likely to be achieved by new instruments in the short term.

${ }^{43}$ See for examples of Europe's activity in this domain, Council Directive 2001/150/EC of 19 December 2001 amending Council Directive 94/57/EC on common rules and standards for ship inspection and survey organizations and for the relevant activities of maritime administrations, [2002] OJ L19/9; Council Decision of 19 December 2002 authorizing the Member States in the interest of the Community, to sign, ratify or accede to the international convention on civil liability for tanker oil pollution damage, 2000 (the Tankers Convention), [2002] OJ L256/7; and Directive 2002/84/EC of the European Parliament and of the Council of 5 November 2002 amending the directives on maritime safety and prevention of oil pollution from ships, [2002] OJ L324/53. These are a few of the European initiatives that were published in 2002, but one could point to many other initiatives showing European activism in this domain as well.

${ }^{44}$ See Amended Proposal of 12 June 2002 for a regulation of the European Parliament and of the Council on the Establishment of a Fund for the Compensation of Oil Pollution Damage in European Waters and Related Measures. [2002] OJ C227E/487.
}

owners, characterized by a tradition of self-regulation in maritime insurance coverage, may compromise the impartial consideration of public (environmental) interests in liability rule development and implementation. ${ }^{45}$ Indeed, in an attempt to stave off the prospect of additional liability burdens on tanker owners, the International Group of P\&I Clubs has recently proposed voluntary increases in the limits of liability for smaller vessels under the CLC Protocol 1992, to be applicable to damage in States opting for the new third-tier compensation fund ${ }^{46}$ Post-Erika, the close cooperation of private shipping actors in the oilpollution liability regime is being scrutinized over its public accountability. It was considered to give low or no incentives for the industry to use ships of high quality, and to give inadequate coverage for environmental damage.

\section{THE 2000 AMENDMENTS}

At the IMO Legal Committee meeting in October 2000 , resolutions were passed that will increase the limits of the 1992 protocols by $50 \%$, which would take effect from November 2003. The proposal of a third tier of compensation, which was originally developed by the European Commission, was taken up by the IMO. This opt-in supplementary fund applies only in States that ratify the protocol. The operation of the 1992 protocols remains therefore unaffected.

The compensation limits set by the 2000 amendments are as follows:

- for a ship not exceeding 5000 gross tonnage, liability is limited to 4.51 million SDR (about US $\$ 5.78$ million) - under the CLC Protocol 1992, the limit was 3 million SDR;

- for a ship of 5,000-140,000 gross tonnage, liability is limited to 4.51 million SDR (about US $\$ 5.78$ million) plus 631 SDR (about US $\$ 807$ ) for each additional gross tonne over 5000 tonnes - under the CLC Protocol 1992, the limit was 3 million SDR plus 420 SDR for each additional gross tonne;

- for a ship over 140,000 gross tonnage, liability is limited to 89.77 million SDR (about US $\$ 115$ million) - under the CLC Protocol 1992, the limit was 59.7 SDR.

It is still too early to review the impact of these amendments since they will only enter into force in November 2003. However, the European Commission does not seem satisfied with these amendments since,

\footnotetext{
${ }^{45}$ See P. Bennett, n. 18 above, at $13-21$

${ }^{46} \mathrm{M}$. Mason, Transnational Compensation for Oil Pollution Damage: Examining Changing Specialties of Environmental Liability (Environment and Society Research Unit Seminar, University College London. March 2002).
} 
as a reaction to the Prestige incident, it proposed stronger measures and even higher limits. ${ }^{47}$

\section{A FEW CRITICAL ISSUES}

\section{LIMITS OF LIABILITY}

The history of oil-pollution liability so far shows that the conventions seem to be reactive, in the sense that they are successively amended after each new incident shows again that the previously agreed limits were insufficient to meet - again - greater oil spills. Hence, the CLC 1969 (which entered into force in 1975) was strengthened with a protocol in $1976,{ }^{48}$ in 1984 (although those protocols did not enter into force), in 1992, and then most recently amended in 2000 . This constant changing of the regime raises the fundamental question of whether there should be a limitation of liability at all. The limits on liability have been critically attacked in economic analysis of law, where it has been argued that a financial limit on the exposure to liability of an injurer may dilute the incentives for prevention..$^{49}$ According to some scholars, limits on liability lead to a 'de-responsibilization' of the industry involved..$^{50}$ They argue that the unbreakable limits should be replaced by a principle whereby the tanker owner can only enjoy a limitation if the incident has not been caused by his negligence. ${ }^{51}$ It is also argued that limitations on liability could be contrary to the polluter-pays principle and that polluters should be fully exposed to the damage they may cause, thereby providing an appropriate (economic) incentive for prevention. ${ }^{52}$ The European Commission has already announced as a follow up to the Prestige incident that the limits, which were increased in 2000, were apparently again too low as was showed by the Erika incident in 1999. The Commission therefore aims to have a total available amount in compensation of approximately \$US1 billion..$^{53} \mathrm{~A}$ part of this compensation will probably be paid by a European compensation fund and not necessarily by the responsible parties. Moreover, just after finishing this article, the IMO

\footnotetext{
${ }^{47}$ Communication from the Commission to the European Parliament and to the Council of 20 December 2002 on Improving Safety at Sea in response to the Prestige Accident, COM (2002) 681 final.

${ }^{48}$ The change was necessary to change the currency from the old point carre franc to the special drawing rights (SDR) as used by the IMF.

${ }^{49}$ See M. Faure and D. Grimeaud, 'Financial Assurance Issues of Environmental Liability', in M. Faure (ed.), Deterrence, Insurability, and Compensation in Environmental Liability. Future Developments in the European Union (Springer, 2003), at 194-206.

${ }^{50}$ See K. Le Couviour, n. 11 above, at 2271.

${ }^{51}$ lbid., at 2272-2273.

${ }^{52}$ W. Erne-Heintz, 'Alors quoi de neuf depuis l'Erika? Le naufrage du Prestige', 29 Journal des Accidents et des Catastrophes (2002).

${ }^{53}$ G.J. Van der Ziel, 'De olieramp met de "Prestige" ', Tijdschrift voor Milieuaansprakelijkheid (2003), at 7.
}

adopted a supplementary compensation fund for oilpollution damage, bringing the available amounts up to 750 SDR, just over US $\$ 1$ billion. This is therefore exactly the amount desired by the European Commission. However, the communication of the Commission in response to the Prestige accident also referred to a stricter application of the polluter-pays principle, referring once more to the fact that the limits of liability of the ship owner should not be unbreakable and that the international regime today does not provide for adequate compensation. ${ }^{54}$

\section{COMPULSORY INSURANCE}

Of course it seems attractive to argue in favour of unlimited liability. However, if tanker owners can circumvent this unlimited liability (by, for instance, the erection of so-called single-ship companies) or if they can otherwise organize their own insolvency, unlimited (or increased) liability of the tanker owner may remain a dead letter. Therefore, it is of crucial importance that liability is accompanied with a duty to seek financial coverage for the liabilities. This is of course already the case today in the CLC Protocol 1992. However, the control of moral hazard with a view of promoting prevention by the current insurers (the P\&I club) seems to be sub-optimal. P\&I clubs are organized as mutuals ${ }^{55}$ and, given the relatively low limits, they have too few incentives to punish negligent ship owners who create risks of oil pollution. ${ }^{56}$

Moreover, the insurability argument is today used as the argument to introduce financial caps on oilpollution damage. It might be better to limit the duty to seek coverage to an insurable amount and to keep the tanker owner fully liable for the remaining risk. This may provide additional incentives for prevention. The current generalized (conventional and statutory) caps should probably be replaced by a mechanism that allows differentiation between injurers (and their available assets) and the potential accidents (and the correspondent magnitude of the loss). Thus, the duty to seek insurance coverage could be better linked to the risk than is the case today, and insurance premiums would truly reflect the risk caused by particular dangerous tankers. ${ }^{57}$ The generalized legislative caps that are in existence today seem too unbalanced

\footnotetext{
${ }^{54}$ See Communication from the Commission to the European Parliament, $\mathrm{n} .47$ above; also Communication from the Commission of 5 March 2003, Report to the European Council on action to deal with the effects of the Prestige disaster (hereinafter Prestige Communication) COM (2003) 105 final.

55 'Mutuals' in this context means that the P\&l clubs are organized under risk-sharing agreements whereby they mutually share each other's losses. Risks are then not shifted to a third party (the insurer) but mutually shared between all those exposed to the same risk.

${ }^{56}$ See K. Le Couviour, n. 11 above, at 2271.

${ }^{57}$ See W. Erne-Heintz, n. 52 above.
} 
and have possibly a negative influence on the incentives to prevent oil pollution.

\section{CHANNELLING OF LIABILITY}

An issue that has been increasingly discussed as critical is the channelling of liability to the tanker owner. It has been defended on practical grounds. Channelling would avoid an economically wasteful duplication of exposure to claims. ${ }^{58}$ The pragmatic advantages may be obvious. The disadvantages are obvious as well: many other persons, such as employees, the charterer or other third parties who could have contributed to the prevention of oil pollution, are now totally excluded from liability as a result of the channelling provisions in the CLC Protocol 1992. Hence, their incentives for prevention are diluted. This again is seen as a feature of 'de-responsibilization'. ${ }^{59}$

Again, with a view on the polluter-pays principle, several authors hold that the channelling of liability should be abrogated. ${ }^{60}$ This approach receives some important support from the European Commission as well. In the communication in response to the Prestige accident, the Commission invited Member States to support proposals aimed at 'removing the de facto immunity of other key players, in particular the charterer, operator or manager of the ship from compensation claims (other than from recourse claims by the registered owner)'. ${ }^{61}$ However, some argue that a disadvantage of setting the channelling aside would be that it will lead to a duplication of procedures and may therefore lead to lengthy procedures, whereby victims may have to wait for years before they are compensated. ${ }^{62}$

These counter-arguments are not convincing. Although channelling is undoubtedly beneficial for the industry and the exclusivity of liability has some pragmatic appeal, the disadvantages seem to be overwhelming, not only as far as prevention, but also as far as compensation is concerned. Moreover, there could be joint and several liability between the various parties who contributed to the risk. Hence, the abrogation of channelling should not necessarily mean that changes should be made to the current system of strict liability of the tanker owner with additional compensation from the Fund.

\footnotetext{
${ }^{58}$ See, for instance, M. Jöransson, n. 26 above, at 95-96.

${ }^{59}$ See K. Le Couviour, n. 11 above, at 2270-2271.

60 lbid., at 2276.

${ }^{61}$ See Communication from the Commission to the European Parliament, n. 47 above.

${ }^{62}$ See G.J. Van der Ziel, n. 53 above, at 7. This author, however, assumes that the current strict liability regime would be replaced by a negligence regime.

(c) Blackwell Publishing Ltd. 2003
}

\section{EXCLUSION OF ECOLOGICAL DAMAGE}

A final critical issue that might lead to changes is the fact that the IOPC Fund, as result of the pollution damage definitions in the 1992 protocols, only intervenes for the costs of reasonable measures of reinstatement. The CLC Protocol 1992 states in its definition of 'pollution damage' that the polluter may be held liable for 'impairment of the environment other than the loss of profit from such impairment, limited to the cost of reasonable measures of reinstatement actually undertaken or to be undertaken', ${ }^{63}$ What is meant with this rather vague and undefined notion has been largely discussed (and criticized) by Brans. He argues that it is not only difficult to find out what restoration measures are considered to be reasonable, but that irreparable harm to the environment itself will not be compensated since the IOPC Fund only compensates economically quantifiable losses. ${ }^{64}$ It is indeed well known from the literature that ecological damage stricto senso cannot be compensated, but that preventive measures can. ${ }^{65}$ Although this issue is heavily criticized, ${ }^{66}$ there may be some economic reasons, based on insurability, to limit compensation to quantifiable losses. Experience in Europe with environmental insurance has so far also shown that, for instance, damage to biodiversity is not compensatable under insurance, but reasonable costs of restoration are. This has led to debate concerning the scope of coverage of a future European environmental liability regime ${ }^{67}$ However, the definition of "pollution damage' is apparently an issue that is also on the agenda for reform. Indeed, in the communication in response to the Prestige accident, the European Commission criticized the fact that the international oil-pollution regime today does not provide for adequate compensation for damage to the environment as such. ${ }^{68}$

\section{POSSIBLE FUTURE DEVELOPMENTS}

This discussion of the critical issues obviously shows the possible direction of future developments. An important issue for reform is obviously the capping of liability. Indeed, the evolution of the conventions makes clear that limits were increased every time after new incidents occurred. When the new 2000 amendments had just been adopted - inter alia as a result

\footnotetext{
${ }^{63}$ CLC Protocol 1992, n. 5 above, Article 6(a).

${ }^{64}$ See E.H.P. Brans, n. 6 above, at 344-360.

${ }^{65}$ See M. Remond-Gouilloud, Quel avenir pour les Conventions de Bruxelles sur l'indemnisation des mars noires (DMF, 1993), at 92-94.

${ }^{66}$ See, for instance, W. Erne-Heintz, n. 52 above.

${ }^{67}$ See M. Faure and D. Grimeaud, n. 49 above, at 129-144

${ }^{68}$ See Prestige Communication, n. 54 above.
} 
of the Erika disaster - another major disaster with the tanker Prestige caused more new challenges to the international regime. The amount available on the basis of the current regime for the Prestige disaster is approximately $\mathbf{1 7 1 . 4 1}$ million euros. ${ }^{69}$ It is yet still too early to judge whether this amount will be sufficient to cover the actual damage, but it is likely that this will not be the case. Hence, the European Commission is once more arguing that the new regime is already outdated before it enters into force in November 2003. Higher limits or even unlimited liability will probably again be on the agenda. ${ }^{70}$ Apparently important steps have already been taken since the IMO adopted a supplementary fund in May 2003 bringing the available amounts to just over US $\$ 1$ billion.

Proposals from different sectors of industry mostly favour preserving the existing balance of measures to facilitate compensation. To maintain equitable sharing, P\&I clubs have proposed a voluntary increase in the limits applicable to small ships for States that are party to the supplementary fund.

Other concrete proposals have been formulated to amend the existing regimes. First, concerning the adequacy of compensation, the Fund Protocol 1992 requires that all claims must be treated on an equal footing, which may lead to delays in claim settlements for major oil spills. This is considered to run counter to the idea of prompt compensation. One alternative may be to establish an order of priority for different classes of claims, which may accelerate the damagecompensation procedure in some cases. ${ }^{71}$

Second, there is a need to reform the channelling of liability. ${ }^{72}$ By channelling the liability to the registered owner of the ship to the exclusion of other parties, such as the charterer, manager or operator, channelling fails to discourage the use of sub-standard ships. ${ }^{73}$ In addition, one could argue that the liability regime should be much more closely linked to the risk posed by the ship. Obviously it is the primary task of conventions aimed at promoting safety at sea to, for instance, phase out single-hulled ships. However, one could also argue that at the liability and insurance level, these 'riskier' ships should either be exposed to higher (or even unlimited) liability (although one could question the effectiveness of this, given the insolvency risk), or at least to higher premiums, reflecting the higher risk they pose.

\footnotetext{
${ }^{69}$ See G.J. Van der Ziel, n. 53 above, at 7.

${ }^{70} \mathrm{lbid}$.

71 See A.H.E. Popp, n. 31 above, at 11-13.

${ }^{72}$ See K. Le Couviour, n. 11 above, at 2276.

${ }^{73}$ At a seminar at the London Shipping Law Centre in 2002, it was reported that the European Commission suggested that one of the criteria for deciding whether a compensation regime is satisfactory was whether it discouraged operators from using vessels of less than top quality; see Lloyd's List (3 July 2002), Law Section. Also see A.H.E. Popp, n. 31 above, at 8
}

The current international regime, by providing a combination of channelling of liability and establishment of almost unbreakable limits, provides an effective shield for unscrupulous operators, which could prove harmful in the future. However, channelling does have advantages. Strict channelling and a stringent test for breaking the limitations have undoubtedly contributed to quick settlement of claims. This especially benefits claimants who do not have the financial means to sustain long and costly litigation to establish who is liable and whether, once the responsible party is identified, that party can maintain the right to limit liability. ${ }^{74}$

Although there is thus a clear need for reform, except for the European Commission, so far no specific proposals have been suggested to change dramatically the current regime. The course today is probably not to tamper with the financial aspect of the international scheme. Another preferable course might be to focus on appropriate modifications to international conventions aimed at maritime safety, such as $\mathrm{MARPOL}^{75}$ and SOLAS, ${ }^{76}$ as well as promoting greater vigilance under the various port State control agreements, to address the problem of sub-standard ships and their operators. A well-known remedy at the safety level, advanced by many, is the mandatory use of so-called double-hull ships and the phasing out of single-hull ships. ${ }^{77}$ Indeed, prevention is always better than cure. These are issues that will probably be high on the political agenda in the future. Typical in this respect is the reaction of the European Commission after the Prestige accident, which immediately issued a communication. ${ }^{78}$ The Commission suggested that Member States should support proposals aimed at restricting the right of ship owners to limit their financial liability if the accident is due to their actual fault. Again, the channelling of liability is criticized and hence the Commission pleads in favour of 'removing the de facto immunity of other key players, in particular the charterer, operator, or manager of the ship from compensation claims (other than from recourse claims by the registered owner)' ${ }^{79}$ Finally, the Commission also

\footnotetext{
${ }^{74}$ See G.J. Van der Ziel, n. 53 above, at 7.

${ }^{75}$ International Convention for the Prevention of Pollution by Ships (MARPOL) (London, 2 November 1973) and Protocol Relating to the International Convention for the Prevention of Pollution from Ships (London, 17 February 1978).

${ }^{76}$ international Convention for the Safety of Life at Sea (SOLAS) (London, 1 November 1974).

${ }^{77}$ Proposal for a Regulation of the European Parliament and of the Council of 20 December 2002 amending Regulation (EC) No 417) 2002 on the accelerated phasing in of double hull or equivalent design requirements for single hull oil tankers and repealing Council Regulation (EC) No $2978 / 94$ (presented by the Commission), COM (2002) 780 final.

${ }^{78}$ See Communication from the Commission to the European Parliament, n. 47 above.

${ }^{79}$ Ibid., at 7.
} 
points to the fact that the international regime does not provide for adequate compensation for damage to the environment as such, and specifically ecological restoration. ${ }^{80}$ That is hence the third issue that will be high on the agenda for reform.

In summary, it may be clear that the oil-pollution compensation regime could have been considered revolutionary and innovative in 1969 when a strict liability regime with compulsory insurance and (at that time) reasonably high amounts of compensation were introduced. However, not only as a result of growing environmental awareness, but more specifically since it became clear that the amount provided for in the regimes did not satisfactorily address large losses, the idea today is that this international regime, providing almost unbreakable limits with exclusive liability of the tanker owner, provides in fact better protection for industry than victims. It should therefore not be surprising to see that, for instance, as a result of the Amoco Cadiz incident, victims were happy to notice that the USA was not a party to the conventions, thus allowing them to bring actions in US courts, ${ }^{81}$ and enabling a larger amount of compensation than they would have received under the CLC regime. This action, showing that victims prefer to circumvent the regimes (with its channelling and financial caps) casts serious doubt on the effectiveness of the international regimes today. At least the European Commission is now convinced that the regimes that came into being in 1969/1971 are outdated and should be seriously reformed.

\section{CONCLUSIONS}

The starting point for this overview was the question whether the international conventions regulating the compensation for oil-pollution damage were effective. This article has tried to sketch the evolution of the relevant international conventions and more particularly the evolution in the amounts of compensation available. The issue of financial caps merits specific attention because of the differences and variations in the amount of the caps. When, on the occasion of every new major incident, it became clear that the amount of the previously adopted caps was too low, protocols and amendments were introduced to raise the amount to more realistic levels. That obviously raises the question whether liability should be limited at all. One can increasingly notice criticism of the international oil-

\footnotetext{
80 lbid.

${ }^{81}$ For a discussion of the Amoco Cadiz case, see, e.g., W. Pfennig storf, "Amoco Cadiz" vor Gericht - Zehn Jahre und kein Ende', 45 Versicherungsrecht, (1988), 1201-1207. Also C. Nigel, Oil Spill Compensation (Shanghai Seminar on Pollution Compensation in China, June 2001).
}

pollution compensation regimes, not only from economists, but also from environmentalists, arguing that the regimes mainly provide protection to tanker owners and the oil industry, but do not guarantee effective compensation for (ecological) damage. Even today, after the many changes the CLC regime has endured, the regime is still criticized, not only because the question arises of whether the financial limits will be adequate to provide compensation for recent catastrophes, such as the sinking of the Prestige, but also because the conventions traditionally did not provide compensation for so-called ecological damage.

The basic argument against financial caps assumes that the injurer has assets at stake that exceed the amount of the financial cap and that the expected amount of the damage will equally be higher than the cap. In the case of a judgment-proof problem, the appropriate answer is obviously not to limit liability to the amount the injurer has at stake, but to seek insurance coverage. Through diversified contractual arrangements between the insurer and the injurer an optimal amount of coverage can be determined in an individual case.

This economic idea, that exposure to liability will provide adequate incentives for accident prevention, has also been stressed by the European Commission, which recently argued that one of the criteria for deciding whether a compensation regime was satisfactory is whether it discourages operators from using vessels of less than top quality. This shows that the European Commission is well aware of the fact that there is a relationship between the exposure to liability of an operator and the incentives to take adequate preventive measures.

However, one should be careful of quickly concluding from economic analysis at the normative level that financial caps should be absolutely abolished. Such action will not guarantee that sufficient coverage will be available and, hence, that incentives for appropriate prevention will be met. Tanker owners might even (but this is also the case under financial caps) have incentives to organize their own insolvency (for instance by limiting the amount of available assets in a corporation). ${ }^{82}$ However, the mere fact that the corporate world may seek ways to organize their own insolvency (which may thus cause under-deterrence) ( $^{8.3}$ should, within the scope of liability law, not be a reason for financial caps. Appropriate remedies might be sought in corporate law (such as piercing the

\footnotetext{
${ }^{82}$ For critical comments concerning these single-ship companies see K. Le Couviour, n. 11 above, at 2273

${ }^{83}$ 'Under-deterrence' is the well-known problem that in the absence of full exposure to liability, the injurer will not be sufficiently deterred and hence will lack appropriate incentives to prevent accidents.
} 
corporate veil), allowing victims to seize assets of a mother company in case of damage caused by a subsidiary. Incentives for responsible behaviour by tanker owners could also be provided through codes of good corporate behaviour. This may fit exactly within the modern tendency to stress the importance of corporate socially responsible governance.

Finally, it is necessary to stress that this article provided 'one view of the cathedral', by discussing only the international regime for the compensation of oilpollution damage. The article discussed the compensation issue from the belief that the exposure of liability of a potential injurer will provide efficient incentives for prevention. However, it is well known from the literature that the prevention of accidents cannot be achieved only through liability rules, but that regulation is needed as well. ${ }^{84}$ Hence, the effectiveness of the international regime aimed at the prevention of oil-pollution spills is crucial. Prevention is always better than cure. Moreover, legal remedies can only, to a limited extent, hope to influence the behaviour of social actors. A true change towards ecological behaviour of those in the oil industry will only be achieved if the norms of responsibility are truly internalized and if the oil industry becomes aware that responsibility for, and prevention of, oil spills and providing adequate compensation is an essential part of their duty towards socially responsible governance. However, the public at large should equally be aware of the fact that increased preventive measures and increased compensation always come at a price: these (necessary and efficient) steps will undoubtedly lead to increases in oil prices, which the public must in the end be willing to pay.

Michael Faure is Professor of Comparative and International Environmental Law and Academic Director of METRO, the Institute for Transnational Legal Research of the University of Maastricht.

Wang Hui is a Ph.D. student at the Catholic University of Leuven.

\footnotetext{
${ }^{84}$ See for the general arguments S. Shavell, 'Liability for Harm versus Regulation', Journal of Legal Studies (1984), at 357-374; and for an application to environmental issues, M. Faure, n. 49 above, at $40-46$.

(9) Blackwell Publishing Ltd. 2003.
} 